University of Nebraska - Lincoln

DigitalCommons@University of Nebraska - Lincoln

Faculty Publications: Agricultural Leadership, Education \& Communication Department
Agricultural Leadership, Education \& Communication Department

$6-2006$

\title{
Scale Development and Construct Clarification of Servant Leadership
}

John E. Barbuto

University of Nebraska - Lincoln, jbarbuto@unlnotes.unl.edu

Daniel W. Wheeler

University of Nebraska - Lincoln, dwheeler1@unl.edu

Follow this and additional works at: https://digitalcommons.unl.edu/aglecfacpub

Part of the Other Public Affairs, Public Policy and Public Administration Commons

Barbuto, John E. and Wheeler, Daniel W., "Scale Development and Construct Clarification of Servant Leadership" (2006). Faculty Publications: Agricultural Leadership, Education \& Communication Department. 51.

https://digitalcommons.unl.edu/aglecfacpub/51

This Article is brought to you for free and open access by the Agricultural Leadership, Education \& Communication Department at DigitalCommons@University of Nebraska - Lincoln. It has been accepted for inclusion in Faculty Publications: Agricultural Leadership, Education \& Communication Department by an authorized administrator of DigitalCommons@University of Nebraska - Lincoln. 


\title{
Scale Development and Construct Clarification of Servant Leadership
}

\author{
John E. Barbuto, Jr. \\ Daniel W. Wheeler
}

University of Nebraska-Lincoln

\begin{abstract}
This article presents an integrated construct of servant leadership derived from a review of the literature. Subscale items were developed to measure 11 potential dimensions of servant leadership: calling, listening, empathy, healing, awareness, persuasion, conceptualization, foresight, stewardship, growth, and community building. Data from 80 leaders and 388 raters were used to test the internal consistency, confirm factor structure, and assess convergent, divergent, and predictive validity. Results produced five servant leadership factors - altruistic calling, emotional healing, persuasive mapping, wisdom, and organizational stewardship - with significant relations to transformational leadership, leader-member exchange, extra effort, satisfaction, and organizational effectiveness. Strong factor structures and good performance in all validity criteria indicate that the instrument offers value for future research.
\end{abstract}

Keywords: servant leadership, scale development, construct clarification

Since Greenleaf's (1970) thought-provoking essay, several scholars and practitioners have embraced the concept of servant leadership. Although this concept is elusive, there appears a practical credibility that has spawned increased attention to servant leadership. This demand stems entirely from the intuitive appeal of the philosophies surrounding servant leadership because no empirical operationalization exists. Servant leaders are described as categorically wise, and their decision processes and service orientations appear to be vehicles for invoking organizational wisdom, described as the meshing of applied knowledge and informed experience to make both optimal and altruistic choices (Bierly, Kessler, \& Christensen, 2000). A service-oriented philosophy of and approach to leadership is a manifestation of and an antecedent to enabling a wise organization. Servant leaders have been described as capable of managing the various paradoxes of decisions, which may foster the development of organizational wisdom (Srivastva \& Cooperrider, 1998). Although specific links between servant leadership and wisdom have been both vague 
and conjectural, their philosophical compatibilities are noteworthy. To advance this dialogue, a more precise clarification of the servant leadership construct is necessary.

Most academic research efforts have focused on conceptually similar constructs such as altruism (Grier \& Burk, 1992; Kanungo \& Conger, 1993; Krebs \& Miller, 1985), self-sacrifice (Choi \& Mai-Dalton, 1998), charismatic (Conger \& Kanungo, 1987; Weber, 1947), transforming (Burns, 1978), authentic (Bass \& Steidlmeier, 1999; Price, 2003), spiritual (Fry, 2003), and, to a lesser extent, transformational (Bass, 1985; Bass \& Avolio, 1994) and leader-member exchange (LMX; see Graen \& Uhl-Bien, 1995). In recent years, greater attention has been paid to the conceptual underpinnings and development of servant leadership as a viable construct (see Graham, 1991; Sendjaya \& Sarros, 2002). However, the empirical examination of servant leadership has been hampered by a lack of theoretical underpinnings and no suitable measure.

This work addresses the conceptualization and measurement of the servant leadership construct. A review of the servant leadership literature and that of similar constructs has led to the development of operational definitions for 11 servant leadership dimensions. Scale development procedures are described in several stages, leading to empirical examination of internal reliability and convergent, divergent, and predictive validity. A refinement of the construct of servant leadership results from the scale development and validation process.

\section{Servant Leadership}

Greenleaf (1970) described a new leadership philosophy, one that advocates the servant as leader:

It begins with the natural feeling that one wants to serve, to serve first. Then conscious choice brings one to aspire to lead. The difference manifests itself in the care taken by the servant-first to make sure that other people's highest priority needs are being served. The best test is: Do those served grow as persons; do they, while being served, become healthier, wiser, freer, more autonomous, more likely themselves to become servants? (p. 4)

Several scholars have tackled the construct since Greenleaf's seminal work, but no consensual framework has emerged.

\section{Servant Leadership Viewpoints}

Graham (1991) conceptualized servant leadership, distinct from charismatic and transformational leadership, framed within four classifica- 
tions of charismatic leadership: Weberian charismatic authority, personal celebrity charisma, transformational leadership, and servant leadership. Graham identified servant leadership as the most moral of charismatic effects. Graham identified its salient characteristics as humility, relational power, autonomy, moral development of followers, and emulation of leaders' service orientation. Servant leadership was described as synonymous with Burns's (1978) original conceptualization of transforming leadership. Graham's discussion distinguished between transformational leadership, described by Bass and associates (see Bass, 1985, 2000; Bass \& Avolio, 1994), and servant leadership by focusing on moral development, service, and enhancement of common good.

Akuchie (1993) explored the biblical roots of servant leadership and explored the religious and spiritual articulations of the construct. However, this work did not articulate a clear framework for understanding servant leadership, as distinct from other forms of leadership. Others have drawn close ties to biblical figures (see Hawkinson \& Johnston, 1993; Snodgrass, 1993), but this approach has been tangential to the larger body of servant leadership literature.

Spears (1995) extended Greenleaf's work by articulating 10 characteristics of a servant leader-listening, empathy, healing, awareness, persuasion, conceptualization, foresight, stewardship, commitment to the growth of people, and community building. This work did not connect to or distinguish itself from other conceptualizations of leadership as Graham's (1991) work had; however, it did provide the closest representation of an articulated framework for what characterizes servant leadership.

Farling, Stone, and Winston (1999) presented a hierarchical model of servant leadership as a cyclical process, consisting of behavioral (vision, service) and relational (influence, credibility, trust) components. It was unclear how this conceptualization differed from better-understood leadership theories such as transformational leadership (Bass, 1985).

Bass (2000) discussed transformational leadership and its relationship with other theories, including servant leadership. In this work, servant leadership was described as having a number of parallels with transformational leadership (vision, influence, credibility, trust, and service), but it moved beyond transformational leadership with its alignment of leaders' and followers' motives.

Polleys (2002) explored servant leadership and distinguished it from three predominant leadership paradigms - the trait, the behavioral, and the contingency approaches to leadership. Polleys's views closely aligned transforming leadership (Burns, 1978) with servant leadership but made no distinctions among charismatic, transformational, and servant leadership. 
Sendjaya and Sarros (2002) examined the research viability of servant leadership, studying its philosophy dating back to religious scriptures. They argued that servant leaders view themselves as stewards and are entrusted to develop and empower followers to reach their fullest potential. However, this work did not develop or propose a testable framework, and no connection to or distinction from other constructs were described.

Barbuto and Wheeler (2002) described servant leadership as composed of 11 characteristics built on the more influential works in the field (e.g., Greenleaf, 1970; Spears, 1995). This framework specified calling as fundamental to servant leadership and consistent with Greenleaf's original message. This work was geared for practitioners and lacked the theoretical development necessary to advance the servant leadership construct to an operational level.

\section{Tangential Concepts}

Many scholars have written about similar concepts, using terms such as self-sacrifice (Choi \& Mai-Dalton, 1998), egalitarianism (Temkin, 1993), prosocial behavior (Bar-Tal, 1976; Brief \& Motowidlo, 1986; Eisenburg, 1982), altruism (Avolio \& Locke, 2002; Grier \& Burke, 1992; Kanungo \& Conger, 1993; Krebs \& Miller, 1985), spiritual leadership (Fry, 2003), authentic leadership (Price, 2003), and stewardship (Block, 1996; Davis, Schoorman, \& Donaldson, 1997). Notions of service, selflessness, and positive intentions are tantamount to each of these concepts.

Among the most researched theories of leadership is the full range model, conceived under the auspices of transforming (Burns, 1978) and later operationalized as transformational leadership (Bass, 1985; Bass \& Avolio, 1994). Transformational leadership now consists of intellectual stimulation, individualized consideration, inspirational motivation, and idealized influence (Bass, 2000). Servant leadership, which was conceived 8 years earlier than was transforming, has received minimal attention in the field. Our review of the field yielded more meta-analyses of transformational leadership than original empirical studies of servant leadership.

LMX theory shares some tenets with servant leadership, particularly in the context of high-quality exchanges, represented by the in-group (Graen \& Uhl- Bien, 1995). In LMX theory, high-LMX leaders develop trusting and mutually beneficial relationships with employees, just as servant leaders develop strong supportive relationships with all employees and colleagues (Greenleaf, 1996). This framework explicitly delineates the leader's characteristics in the relationship, whereas LMX theory provides a normative description of the relationship.

Smith, Montagno, and Kuzmenko (2004) compared transformational with servant leadership and identified differences based on the types of 
cultures created by each, and they also discussed contextual factors that may precipitate one style over the other. We describe servant leadership as distinct from transformational leadership and LMX theories (see Table 1) using roles of leaders or followers, moral intent, expected outcomes, and levels of analysis (individual, interpersonal, group, organization, society). LMX theories are more descriptive than normative, so practical assumptions are implicit in our analysis.

\section{Summary of Literature: Toward an Integrative Framework and Operational Definitions}

Despite several conceptual papers on the topic of servant leadership, there is no consensus construct for empirical research. Most papers have standalone qualities, but the work to date has not evolved, with seemingly more differentiation than integration in the literature. Greenleaf $(1970,1972)$ and Spears $(1995,2002)$ are the most accepted views driving the field, so any operational work on servant leadership should begin with their major tenets.

The framework proposed by Barbuto and Wheeler (2002) combines the 10 characteristics of Spears (1995) with the dimension calling-the natural desire to serve others, which was fundamental to servant leadership in the early writings of Greenleaf (e.g., 1970, 1972, 1974, 1996). The desire to serve was embedded in all conceptualizations of servant leadership (e.g., Akuchie, 1993; Farling et al., 1999; Graham, 1991; Polleys, 2002; Sendjaya \& Sarros, 2002). We develop operational definitions and scales to measure 11 potential characteristics of servant leadership: calling, listening, empathy, healing, awareness, persuasion, conceptualization, foresight, stewardship, growth, and community building.

Calling. Greenleaf (1970) explained that the motivation of leaders must begin with a conscious choice to serve others. Avolio and Locke (2002) discussed the necessity of altruism in leaders to have the greatest impact on organizations and their members. Choi and Mai-Dalton (1998) described selfless and sacrificial roles that leaders play in organizations to gain respect and loyalty from followers. Fry (2003) described calling, within a spiritual leadership framework, as making a difference and giving one's life meaning. Block (1996) described leaders choosing service over self-interest in terms fundamentally similar to calling. Others have described altruism as similar to that of calling (Grier \& Burk, 1992; Kanungo \& Conger, 1993; Krebs \& Miller, 1985). Bass (2000) described the difference between transformational and servant leadership as being the intentions of leaders - with servant leaders more likely to embrace a selfless objective. We believe that calling is fundamental to servant lead- 
Table 1. Comparing Servant Leadership, Transformational Leadership, and Leader-Member-Exchange (LMX) Theories

\begin{tabular}{|c|c|c|c|}
\hline & $\begin{array}{l}\text { Servant Leadership } \\
\text { Theory }\end{array}$ & $\begin{array}{l}\text { Transformational } \\
\text { Leadership Theory }\end{array}$ & $\begin{array}{l}\text { LMX } \\
\text { Theory }\end{array}$ \\
\hline $\begin{array}{l}\text { Nature of } \\
\text { theory }\end{array}$ & Normative & Normative & Descriptive \\
\hline Role of leader & To serve followers & $\begin{array}{l}\text { To inspire followers } \\
\text { to pursue } \\
\text { organizational goals }\end{array}$ & $\begin{array}{l}\text { To develop positive } \\
\text { relationships } \\
\text { with followers }\end{array}$ \\
\hline Role of follower & $\begin{array}{l}\text { To become wiser, } \\
\text { freer, more } \\
\text { autonomous }\end{array}$ & $\begin{array}{l}\text { To pursue } \\
\text { organizational } \\
\text { goals }\end{array}$ & $\begin{array}{l}\text { To develop positive } \\
\text { relationships } \\
\text { with leaders }\end{array}$ \\
\hline Moral component & Explicit & Unspecified & Unspecified \\
\hline Outcomes expected & $\begin{array}{l}\text { Follower satisfaction, } \\
\text { development, and } \\
\text { commitment to } \\
\text { service, societal } \\
\text { betterment }\end{array}$ & $\begin{array}{l}\text { Goal congruence; } \\
\text { increased effort, } \\
\text { satisfaction, and } \\
\text { productivity; } \\
\text { organizational gain }\end{array}$ & $\begin{array}{l}\text { High } \\
\text { LMX-satisfaction, } \\
\text { mutual trust, } \\
\text { increased effort }\end{array}$ \\
\hline Individual level & Desire to serve & Desire to lead & Desire to relate \\
\hline Interpersonal level & Leader serves follower & $\begin{array}{l}\text { Leader inspires } \\
\text { follower }\end{array}$ & $\begin{array}{l}\text { Leader exchanges } \\
\text { with follower }\end{array}$ \\
\hline Group level & $\begin{array}{l}\text { Leader serves group } \\
\text { to meet members } \\
\text { needs }\end{array}$ & $\begin{array}{l}\text { Leader unites group } \\
\text { to pursue } \\
\text { group goals }\end{array}$ & $\begin{array}{l}\text { Leader develops } \\
\text { different exchanges } \\
\text { with each person }\end{array}$ \\
\hline Organizational level & $\begin{array}{l}\text { Leader prepares } \\
\text { organization to } \\
\text { serve community }\end{array}$ & $\begin{array}{l}\text { Leader inspires } \\
\text { followers to pursue } \\
\text { organizational goals }\end{array}$ & Unspecified \\
\hline Societal level & $\begin{array}{l}\text { Leader leaves a } \\
\text { positive legacy for the } \\
\text { betterment of society }\end{array}$ & $\begin{array}{l}\text { Leader inspires nation } \\
\text { or society to pursue } \\
\text { articulated goals }\end{array}$ & Unspecified \\
\hline
\end{tabular}

ership and have operationalized it as a desire to serve and willingness to sacrifice self-interest for the benefit of others.

Listening. Listening is described as the active acceptance of employees' opinions, ideas, and suggestions (Spears, 1995). Bass and Avolio (1994) described leaders' willingness to entertain even the most outland- 
ish ideas from followers, noting that this pattern of behavior increases follower commitment. Johnson and Bechler (1998) found strong positive relationships between listening skills and leadership emergence. Kramer (1997) tested interpersonal skills and found relationships between listening and transformational leadership effectiveness. Bechler and Johnson (1995) reported a relationship between listening skills and leadership effectiveness. These studies document the importance of listening skills for leadership effectiveness. We operationalized listening as an ability to hear and value the ideas of others.

Empathy. Empathy extends listening when leaders are able to put themselves in the circumstances of others. Wolff, Pescosolido, and Druskat (2002) found empathy to be a key component of emotional intelligence that enables cognitive processes and skills in self-managed teams by providing an understanding of members' emotions and needs. Pescosolido (2002) describes empathy as a crucial characteristic for managers of group emotions in self- managed teams. Shuster (1994) advocated strongly for the importance of empathy. With a framework of spiritual leadership, Fry (2003) advocated compassion within the context of altruistic love, drawing parallels with empathy. These studies demonstrate the importance of empathy in effective leadership. We operationalized empathy as the ability to appreciate the circumstances that others face.

Healing. When people have hopes, dreams, or relationships that fail or end in disappointment, emotional resolution or healing can resolve broken spirits and emotional pain (Spears, 1995). A number of scholars have suggested that healing is among the most powerful skills necessary for effective leadership (Dacher, 1999; Sturnick, 1998). Weymes (2003) posited that the primary purpose of leadership is to influence feelings and emotions to create the emotional heart of the organization. Emmerich (2001) suggested that during hard times leaders must be empathetic and create a forum for people to express feelings. Fry (2003) described spiritual survival of individuals and the needs for forgiveness, acceptance, and humility in terms similar to healing. Although none of these studies uses the term healing, the dimensions studied are part of the process of healing. It appears that healing is an under- appreciated aspect of leadership and is a characteristic that separates servant leadership from most leadership theories. We operationalized healing as an ability to recognize when and how to foster the healing process.

Awareness. Awareness is operationalized as the leader's astuteness for picking up cues in the environment (Barbuto \& Wheeler, 2002). His- 
torically, the importance of great leaders seeking knowledge has been described as one of two key attributes of wisdom (Kant, 1978; Plato, 1945). Recent articulations of wisdom have echoed this view (Bierly et al., 2000; Sternberg, 2003). A great deal of recent work has examined the role of awareness of self and others in leadership phenomena. Sosik and Megerian (1999) studied awareness and self-other perceptions and found relationships with perceptions of transformational leadership. Awareness also plays a significant role as one of the key components of most behavioral models of emotional intelligence (Barling, Slater, \& Kelloway, 2000; Caruso, Mayer, \& Salovey, 2002). Awareness is operationalized as an ability to notice what is happening by picking up cues in the environment.

Persuasion. Leaders using persuasion are able to influence others without relying on formal authority or legitimate power (Barbuto \& Wheeler, 2002). A convincing rationale serves the influence process, much more so than organizational rank (Spears, 1995). Ping and Yukl (2000) tested perceived effectiveness of influence tactics and found rational persuasion to be among the most effective in American cultures. Falbe and Yukl (1992) found that rational persuasion led to more positive outcomes than forceful influence strategies such as exchanges, pressure, coalitions, and legitimating. Bass and Steidlmeier (1999) addressed the importance of persuasion and its interplay with ethics, character, and authentic transformational leadership. These studies demonstrate the importance of being persuasive rather than forceful. Persuasion is operationalized as an ability to influence others by means outside of formal authority.

Conceptualization. Leaders' conceptualization encourages colleagues to use mental models and expand the creative processes (Barbuto \& Wheeler, 2002; Spears, 1995). Awamleh and Gardner (1999) found that the content of leader vision and its delivery were related to organizational performance and effectiveness. Druskat and Pescosolido (2002) reported that leaders' mental models in self-managed teams will produce positive outcomes. Towler (2003) found that visioning skills predict performance of leaders. These findings accentuate the powerful impact of leader conceptualization on organizations. Conceptualization is operationalized as fostering an environment that uses mental models and encourages lateral thinking.

Foresight. Leaders use foresight to anticipate the future for the organization and its members (Barbuto \& Wheeler, 2002; Spears, 1995). Historical philosophy embodied notions of foresight in discussions of wisdom described as extending beyond insights and facts toward proactively nav- 
igating the course of action, anticipating the challenges and consequences (Longman, 2002). Scholars argue that the ability of leaders to envision the future state of the organization is essential to their effectiveness (Avolio, 1999). Farling et al. (1999) argued that the skill of leaders to anticipate and communicate a vision is critical to servant leadership practice. Bierly et al. (2000) argued that, beyond knowledge, leaders must know the appropriate application and context to guide purposeful action. These works speak to the importance of anticipation and foresight to effective leadership. Foresight is operationalized as an ability to anticipate the future and its consequences.

Stewardship. Stewardship involves preparing the organization and its members for great contributions to society (Barbuto \& Wheeler, 2002). Leaders seek to meet the needs of society more than those of the organization. Brief and Motowidlo (1986) discussed prosocial behaviors and the leadership role in social consequences beyond the organization; Coleman (1998) discussed legacy leadership, advocating for leaders to take stewardship roles for society; and Giltmier (1990) described the role of leaders in communities to leave a legacy of sustainability for the environment and natural resources - essentially an environmental stewardship. Stewardship is operationalized as believing organizations have a legacy to uphold and must purposefully contribute to society.

Growth. Greenleaf (1996) reminded us that one of the great outcomes of servant leadership is that followers develop in a positive direction. Godshalk and Sosik (2000) examined the dynamics of the mentorprotégé relationship and found expectations of both parties play a role in the effectiveness of the relationship. Leaders' use of individualized consideration has consistently related to motivation to perform extra work, employee satisfaction, and leadership effectiveness (Lowe, Kroeck, \& Sivasubramaniam, 1996). These findings indicate that leaders who demonstrate a commitment to the growth of employees will experience positive organizational outcomes. Growth is operationalized as an ability to identify others' needs and provide developmental opportunities.

Community building. Organizations have the potential to be communities if people are committed to each other, learn to communicate, and address their issues (Peck, 1998). Goffee and Jones (2001) found strong communities were necessary for followers to exhibit commitment to leaders. Perrewe (2000) described the importance of creating a forum for people to optimally address their issues within the context of political skills. These studies demonstrate that building community leads to follower commitment and organizational identity. Building 
community is operationalized as an ability to instill a sense of community spirit in an organization.

\section{The Conceptual Distinctness of Servant Leadership Characteristics}

We anticipate some overlap among the preceding dimensions of servant leadership, but we have avoided any reduction until empirical evidence warrants. The construct of servant leadership has had no empirical research to indicate its optimal set of dimensions, so the conceptual distinctness of these characteristics is tested with these scale development procedures.

\section{Scale Development}

\section{Initial Item Development}

The purpose of this study was to develop and validate an instrument that captures the 11 characteristics of servant leadership. A process recommended by Hinkin and Schriesheim (1989) and Devellis (1991) began with developing new, conceptually consistent, theoretical definitions of the constructs, as done in the prior section. Next, five to seven sample items were developed for each of the 11 characteristics incorporating structured item development strategies (Devellis, 1991). Items were written for clarity and congruence to Spears's (1995) descriptions where appropriate. After the initial 56 items were developed, the authors reviewed them carefully to eliminate distracting or confusing language and grammar. Approximately 10 to 15 of the initial items were rewritten and/or edited prior to continuing the process. The 56 revised items were then tested for face validity.

\section{Face Validity Assessments of the Subscale Items}

To ascertain the face validity of items and identify poorly written or vague items, a panel of 11 expert judges, consisting of 6 leadership faculty from three universities and 5 advanced leadership doctoral students from one university, performed a priori analysis. Items categorized into 1 of the 11 servant leadership characteristics $60 \%$ of the time (7 of 11 judges) were retained (Hinkin \& Schriesheim, 1989; Revelle \& Rocklin, 1979). Four of the initial 56 items that failed to meet this criterion were rewritten. A final panel of 5 judges (all faculty) reviewed the revised 56 items and correctly categorized all items greater than $80 \%$ (4 out of 5 judges) of the time, indicating face validity of the 56 subscale items. 
Sample

To test the psychometric properties of the questionnaire, we administered it to a sample of 80 elected community leaders and 388 raters from counties in the Midwestern United States. The community leaders attended a leadership development workshop and were members of a statewide professional organization. The average age of participants was 51 years. In all, $50 \%$ had earned a bachelor's degree, whereas $20 \%$ had earned a master's degree or higher. Of the leaders, $65 \%$ were women. Raters were colleagues or employees of the leaders. Raters reported an average age of 46 years. Of the raters, $42 \%$ had earned a bachelor's degree, whereas less than $10 \%$ had earned a master's degree or higher. Of the raters, $53 \%$ were women.

\section{Procedures for External Sampling}

Data were collected from an intact group of elected officials as part of a full-day leadership training seminar for members of an association that sponsors annual professional development programs for its members. The sample is appropriate for studying servant leadership because the role of these elected officials was to serve their communities in public office. Participants filled out the self-report version of the servant leadership instrument 4 weeks prior to the workshop and the self-report version of the multi-leadership behavior questionnaire (MLQ) at the workshop. Each participant was asked to solicit between four and six raters to complete a similar battery of instruments, consisting of the rater version of the servant leadership instrument, the rater version of the MLQ, and the rater version of the LMX-7. Responses to the MLQ and LMX-7 measures were collected to assess the convergent validity between similar constructs.

Instruments were coded to protect the identities of raters; however, leaders' names were kept on a separate coding sheet for interpretation and feedback. All instruments were returned directly to the first author via U.S. mail. Participants and their raters were provided a letter detailing their participation and rights, which included the right to withdraw at any time during the research process. None of the participants asked to be removed from the study. Because elected officials had pre-registered for the conference, the response rate is less relevant; however, 80 of the eligible 88 elected officials participated in the study. This high participation rate indicates that participants were keenly interested in the information.

\section{Varimax Rotation of Items: Data Reduction}

A series of exploratory factor analyses, using the data collected from raters, were conducted in this study. The rater sample was used be- 
cause its sample size $(n=388)$ was more suitable to the rigor of principal component analysis than was the leader sample size $(n=80$; Hurley \& Scandura, 1997). A varimax rotation with Kaiser normalization was used to identify items with strong and unique loadings to components identified in the analysis and to guide potential reduction of factors. A reviewer suggested oblique rotations, which are useful in instances when dimensions may not be orthogonal. However, Fabrigar, Wegener, MacCallum, and Strahan (1999) found that an oblique rotation may produce a slightly better simple structure than a varimax rotation, but the patterns of loadings have usually been the same. After performing the oblique rotation, there were no significant differences with the varimax rotation.

A series of extractions guiding factor and item reductions resulted in 5 factors, as opposed to the 11 proposed (see Table 2).

The reduced set of 23 items resulted in five factors with strong and unique loadings. It appears from this analysis that a refinement of the servant leadership construct is warranted and necessary for research and practice. The resulting factors of servant leadership are labeled altruistic calling, emotional healing, wisdom, persuasive mapping, and organizational stewardship (see the appendix). These five dimensions appear to capture the essence of servant leadership - as separate from the more leader-focused construct of transformational leadership.

\section{Internal Reliability Assessment, Simple Statistics, and Intercorrelations of the} Subscales

Leader and rater versions of the subscales were assessed for their internal reliability using SPSS scale internal reliability (a) functions, which featured a removal of poor item performance function based on item to total factor correlations. The reliabilities of each of the 10 servant leadership subscales ( 5 self, 5 rater) were assessed (see Tables 3 and 4). The self version of the subscales demonstrated reliabilities ranging from .68 to .87. The rater version of the subscales demonstrated reliabilities ranging from .82 to .92 . No opportunities for improving the reliability coefficient alphas for any of the subscales existed.

Simple statistics were calculated for all subscales. Self-rated subscales of servant leadership subscales showed means ranging from 2.48 to 2.98 ( 1 = strongly disagree, 2 = somewhat disagree, 3 = somewhat agree, 4 = strongly agree). The standard deviations were fairly consistent across the five subscales, ranging from 0.49 to 0.58 . For the rater versions of the servant leadership subscales, means ranged from 2.58 to 3.24 . The standard deviations were consistent for rater versions across the five subscales, ranging from 0.73 to 0.97 . In both self and rater versions of the servant lead- 
Table 2. Varimax Rotation Patterns for Servant Leadership Subscales

\begin{tabular}{lccccc}
\hline & \multicolumn{5}{c}{ Components } \\
\cline { 2 - 6 } Subscales & 1 & 2 & 3 & 4 & 5 \\
\hline $28(\mathrm{WI})$ & .858 & .130 & .255 & .137 & .071 \\
$06(\mathrm{WI})$ & .857 & .166 & .127 & .155 & .169 \\
$17(\mathrm{WI})$ & .854 & .175 & .153 & .137 & .148 \\
$50(\mathrm{WI})$ & .838 & .168 & .234 & .162 & .104 \\
$09(\mathrm{WI})$ & .542 & .340 & .241 & .128 & .267 \\
$29(\mathrm{PM})$ & .169 & .727 & .315 & .117 & .262 \\
$40(\mathrm{PM})$ & .151 & .725 & .195 & .243 & .264 \\
$07(\mathrm{PM})$ & .212 & .705 & .116 & .294 & .193 \\
$18(\mathrm{PM})$ & .297 & .698 & .194 & .077 & .091 \\
$09(\mathrm{PM})$ & .072 & .627 & .120 & .275 & .326 \\
$34(\mathrm{OS})$ & .210 & .113 & .792 & .242 & .174 \\
$43(\mathrm{OS})$ & .264 & .291 & .746 & .210 & .111 \\
$21(\mathrm{OS})$ & .284 & .175 & .702 & .114 & .236 \\
$45(\mathrm{OS})$ & .146 & .308 & .604 & .373 & .284 \\
$54(\mathrm{OS})$ & .317 & .399 & .540 & .387 & .081 \\
$01(\mathrm{AC})$ & .174 & .194 & .121 & .726 & .284 \\
$35(\mathrm{AC})$ & .057 & .225 & .177 & .701 & .219 \\
$46(\mathrm{AC})$ & .206 & .251 & .334 & .657 & .263 \\
$03(\mathrm{AC})$ & .277 & .140 & .301 & .636 & .167 \\
$16(\mathrm{EH})$ & .170 & .277 & .253 & .259 & .781 \\
$05(\mathrm{EH})$ & .182 & .248 & .145 & .246 & .778 \\
$27(\mathrm{EH})$ & .180 & .281 & .203 & .294 & .769 \\
$38(\mathrm{EH})$ & .210 & .355 & .242 & .341 & .542 \\
\hline WI & & & & \\
\hline
\end{tabular}

$\mathrm{WI}=$ wisdom $; \mathrm{PM}=$ persuasive mapping; $\mathrm{OS}=$ organizational stewardship $; \mathrm{AC}=$ altruistic calling; $\mathrm{EH}=$ emotional healing. Rotation method: Varimax with Kaiser normalization. Extraction method: principal component analysis with eigenvalue greater than 1.0 extraction criteria. Rotation converged in 13 iterations.

ership questionnaire, wisdom and organizational stewardship were the highest reported characteristics for this sample. Persuasive mapping was the lowest reported characteristic across both self and rater versions. The greatest variability in self-report responses was found for wisdom and persuasive mapping. The greatest variability in rater-report responses was found for emotional healing.

The intercorrelations for self and rater versions of the servant leadership subscales were calculated (see Tables 3 and 4). Subscale intercorrelations ranged from $r=.28$ to $r=.53$ for self versions and from $r=.47$ to $r=.71$ for rater versions of the servant leadership measure. The highest intercorrelation for the self version of the servant leadership questionnaire was between emotional healing and persuasive mapping. The lowest intercorrelation for this population was between altruistic calling and 
Table 3. Self Version of Servant Leadership Questionnaire Reliabilities, Intercorrelations, and Covariates

\begin{tabular}{lllllllll}
\hline Subscales & $\mathrm{M}$ & $\mathrm{SD}$ & 1 & 2 & 3 & 4 & 5 & 6 \\
\hline 1. Altruistic calling (4) & 2.94 & 0.53 & .77 & & & & & \\
2. Emotional healing (4) & 2.48 & 0.49 & .42 & .68 & & & & \\
3. Wisdom (5) & 2.97 & 0.58 & .47 & .45 & .87 & & & \\
4. Persuasive mapping (5) & 2.28 & 0.58 & .28 & .53 & .50 & .83 & & \\
5. Organizational & 2.98 & 0.57 & .47 & .31 & .37 & .48 & .83 & \\
$\quad$ stewardship (5) & & & & & & & & \\
6. Transformational & 2.87 & 0.49 & .43 & .55 & .56 & .56 & .62 & .89 \\
$\quad$ leadership (16) & & & & & & & &
\end{tabular}

Coefficient alphas along diagonal. All correlations significant at $p<.01$.

Table 4. Rater Version of Servant Leadership Questionnaire Reliabilities, Intercorrelations, and Covariates

\begin{tabular}{lccccccccc}
\hline Subscales & M & SD & 1 & 2 & 3 & 4 & 5 & 6 & 7 \\
\hline 1. Altruistic calling (4) & 2.76 & 0.79 & .82 & & & & & & \\
2. Emotional healing (4) & 2.71 & 0.97 & .71 & .91 & & & & & \\
3. Wisdom (5) & 3.24 & 0.71 & .51 & .49 & .92 & & & & \\
4. Persuasive mapping (5) & 2.58 & 0.80 & .62 & .69 & .49 & .87 & & & \\
5. Organizational & 3.12 & 0.73 & .68 & .62 & .58 & .47 & .89 & & \\
$\quad$ stewardship (5) & & & & & & & & & \\
6. Transformational (16) & 3.05 & 0.65 & .25 & .30 & .34 & .29 & .33 & .95 & \\
$\begin{array}{l}\text { 7. Leader-member } \\
\quad \text { exchange (7) }\end{array}$ & 3.15 & 0.69 & .70 & .73 & .55 & .61 & .67 & .38 & .89 \\
\hline
\end{tabular}

Coefficient alphas along diagonal. All correlations significant at $p<.01$.

persuasive mapping. The highest intercorrelation for rater version of the servant leadership questionnaire was between altruistic calling and emotional healing. The lowest intercorrelation was between persuasive mapping and organizational stewardship.

\section{Confirming the Factor Structures of the Subscales}

Confirmatory factor analysis was used to test the factor loading structure of the subscales. This analysis was performed on the leader sample ( $n$ $=80$ ). Using the revised subscales ( 3 to 4 items per subscale), a confirma- 
tory factor analysis was performed. LISREL 8.54 (Jöreskog \& Sörbom, 2003) maximum likelihood confirmatory factor analysis was used for the estimation. Maximum likelihood confirmatory factor analysis makes it possible to assess the goodness of fit of a factor structure to a set of data. Thus, we conducted LISREL analyses on the 23 servant leadership items. Initially, each item was specified as orthogonal, and each of the five revised subscales was treated as not orthogonal. The five factors were set as latent variables.

The overall model fit was indicated by the chi square, $x^{2}(220)=$ $1,410.69, p=.0$, for both versions of the servant leadership subscales. The resulting root mean square error of approximation was .010, and the normed fit index was .96. The non-normed fit index was .96, the comparative fit index was .96, the incremental fit index was .96, and the relative fit index was .95. The data appear to support the five-factor structure.

\section{Convergent and Divergent Validity}

To test the servant leadership subscale's convergent and divergent validity, transformational leadership (leaders and raters) and LMX (raters only) measures were completed by the sample. Results demonstrated strong and consistent patterns between servant leadership and transformational leadership (see Tables 3 and 4). Taken together, transformational leadership and servant leadership appear to share some tenets; however, the low effect sizes indicate they are capturing different phenomena. LMX shared variance with each of the five servant leadership subscales and shared stronger relationships with each of the servant leadership subscales than it did with transformational leadership, providing some support for divergent validity of the servant leadership subscales.

\section{Assessing the Predictive Validity of the Subscales}

To test the predictive validity of the subscales, several outcome variables - motivation to perform extra work, employee satisfaction, and perceptions of organizational effectiveness - were measured (using the MLQ measure for each) and correlated with each of the five subscales of servant leadership (leader and rater versions), the single factor transformational leadership (leader and rater versions), and LMX (rater version only).

Results indicated that self-reported servant leadership subscales correlated positively with each of the three positive outcome variables (see Table 5). Organizational stewardship had the strongest relationship with extra effort. Wisdom and organizational stewardship had the strongest relationships with employee satisfaction. Organizational stewardship had the strongest relationship with perceptions of organizational effectiveness. 
Table 5. Predictive Validity of the Servant Leadership Subscales (Self-Report)

\begin{tabular}{lccc}
\hline Leadership Subscales & Extra Effort & Satisfaction & Effectiveness \\
\hline Altruistic calling & .43 & .39 & .42 \\
Emotional healing & .52 & .35 & .50 \\
Wisdom & .45 & .44 & .51 \\
Persuasive mapping & .48 & .36 & .54 \\
Organizational stewardship & .56 & .44 & .60 \\
Transformational leadership & .67 & .62 & .66 \\
\hline
\end{tabular}

All correlations $p<.05$, power $>.80$ (two-tailed test; $p<.05)$.

Table 6. Predictive Validity of the Servant Leadership Subscales (Rater Report)

\begin{tabular}{lccc}
\hline & \multicolumn{3}{c}{ Rater-Reported Outcomes } \\
\cline { 2 - 4 } Leadership Subscales & Extra Effort & Satisfaction & Effectiveness \\
\hline Altruistic calling & .16 & .23 & .27 \\
Emotional healing & .23 & .44 & .47 \\
Wisdom & .27 & .42 & .49 \\
Persuasive mapping & .20 & .31 & .40 \\
Organizational stewardship & .22 & .36 & .55 \\
Transformational leadership & .84 & .83 & .81 \\
Leader-member-exchange & .37 & .31 & .30 \\
\hline
\end{tabular}

All correlations $p<.05$, power $>.80$ (two-tailed test; $p<.05)$.

For the rater-report subscales, the strongest relationship for employees' motivation to perform extra work was with wisdom. The strongest relationship for employees' satisfaction was with emotional healing. The strongest relationship for perceptions of organizational effectiveness was with organizational stewardship. Each of the subscales shared positive relationships with each of the three positive outcome variables (see Table 6).

Comparatively, transformational leadership shared the strongest variance with the three outcome measures across both self and rater reports. This is consistent with the mono-source, mono-method, mono-measure bias that comes from the instrument's format (Bycio, Hackett, \& Allen, 1995). In these instances, relationships tend to be higher than when multiple sources of data are used. LMX showed a larger effect size than the servant leadership subscales for extra effort and lower effect sizes than servant leadership subscales for satisfaction and perceptions of organizational effectiveness. 
To address the issue of single-method, single-source data, we also assessed the correlates of the self-reported servant leadership subscales with the rater-reported outcomes (see Table 7), as recommended (see Podsakoff \& Organ, 1986). Leaders' self-reported altruistic calling shared significant variance with rater-reported satisfaction with leader. Leaders' self-reported wisdom was related to employees' extra effort, perceptions of effectiveness, LMXs and transformational leadership. Leaders' self-reported organizational stewardship was related to rater-reported perceptions of organizational effectiveness, LMX, and transformational leadership. Leaders' self-reported emotional healing and persuasive mapping were not related to any of the rater-reported outcomes. Convergent and divergent validity of the leaders' self-reported servant leadership subscales is indicated by the low effect sizes with transformational leadership in this iteration of the analysis.

In addition, we assessed the correlates of rater-reported servant leadership subscales with the self-reported outcomes (see Table 8). Rater-reported altruistic calling of leaders was related to leaders' self-reported estimation of employees' satisfaction. Rater-reported persuasive mapping and organizational stewardship shared significant variance with all selfreported outcomes and correlates. LMX also shared variance with all selfreported outcomes and correlates. Comparatively, the rater-reported servant leadership sub- scales shared greater variance than transformational leadership with leader- reported outcomes.

\section{Discussion}

The purpose of this article was to clarify the construct of servant leadership and operationalize it for empirical research. A review of the literature identified 11 potential characteristics that captured the major tenets of servant leadership (Barbuto \& Wheeler, 2002; Greenleaf, 1970; Spears, 1995). To operationalize this construct, items for these characteristics were created and validated. Face validity was achieved by a priori categorization with an $80 \%$ acceptance criterion. Factor analysis reduced the data to five unique subscales, which were used to test reliability, convergent, divergent, and predictive validity. Positive correlations with transformational leadership demonstrated some convergence. Divergence was not tested using the MLQ because of its factor structure. Predictive validity of the servant leadership subscales was evident from the correlations with employees' extra effort, satisfaction, organizational effectiveness, and, to some extent, LMX.

One of the more interesting outcomes of this validation process was how well the subscales performed in correlations with the leadership and 


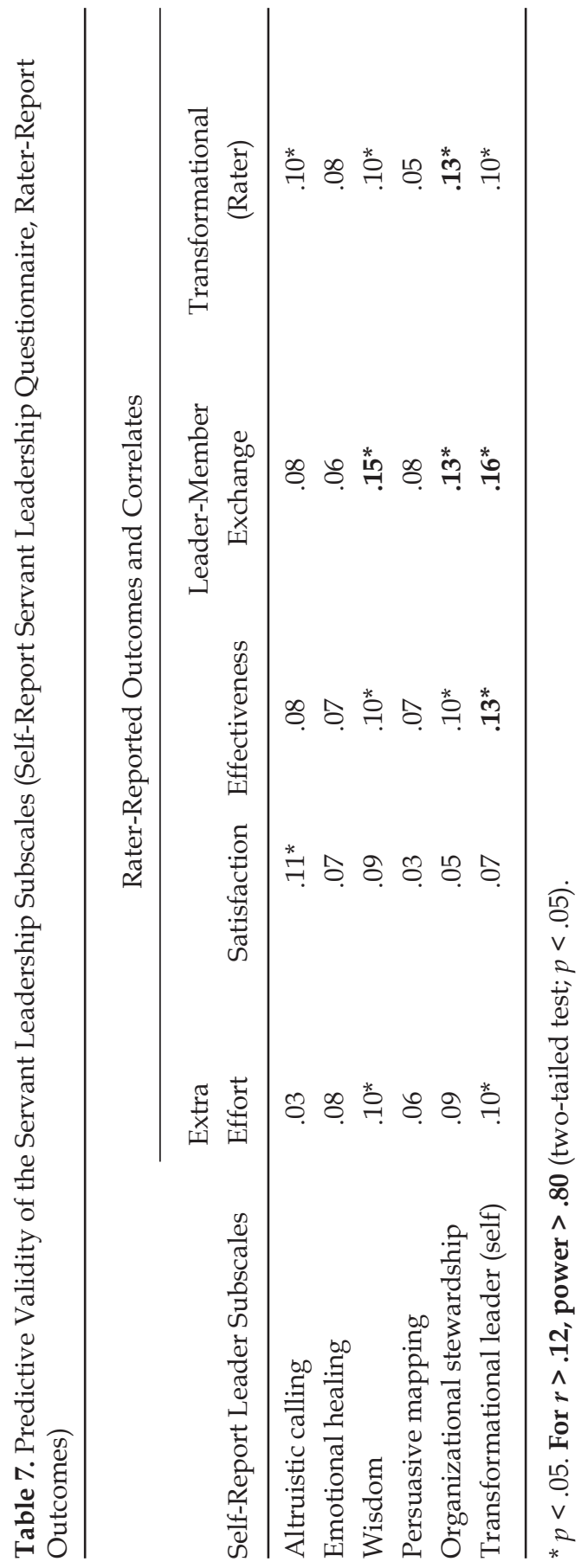


Table 8. Predictive Validity of the Servant Leadership Subscales (Rater-Report Servant Leadership Questionnaire, Self-Report Outcomes)

\begin{tabular}{|c|c|c|c|c|}
\hline \multirow{3}{*}{$\begin{array}{l}\text { Rater-Report Leader } \\
\text { Subscales }\end{array}$} & \multicolumn{4}{|c|}{ Self-Reported Outcomes and Correlates } \\
\hline & Extra & & & Transformational \\
\hline & Effort & Satisfaction & Effectiveness & s $\quad$ (Self) \\
\hline Altruistic calling & .02 & .08 & .04 & .04 \\
\hline Emotional healing & .06 & .05 & .08 & .05 \\
\hline Wisdom & .06 & $.12^{*}$ & .08 & .09 \\
\hline Persuasive mapping & $.19^{*}$ & $.14^{*}$ & $.19 *$ & $.17^{*}$ \\
\hline $\begin{array}{l}\text { Organizational } \\
\text { stewardship }\end{array}$ & $.14^{*}$ & $.14^{*}$ & $.16^{*}$ & $.14^{*}$ \\
\hline Leader-member-exchange & $.11^{*}$ & $.18^{*}$ & $.11^{*}$ & $.16^{*}$ \\
\hline $\begin{array}{l}\text { Transformational } \\
\text { leader (rater) }\end{array}$ & .09 & $.11^{*}$ & .08 & $.10^{*}$ \\
\hline
\end{tabular}

${ }^{*} p<.05$. For $r>. \mathbf{1 2}$, power $>.80$ (two-tailed test; $\left.p<.05\right)$.

outcomes measures. This is particularly promising, given that the MLQ and LMX are more established measures with more than 20 years of research.

\section{Refinement of Servant Leadership: A Five-Dimension Construct}

Factor analyses indicate 5 factors derived from the 11 potential servant leadership characteristics - altruistic calling, emotional healing, wisdom, persuasive mapping, and organizational stewardship-which appear to be conceptually and empirically distinct.

Altruistic calling describes a leader's deep-rooted desire to make a positive difference in others' lives. It is a generosity of the spirit consistent with a philanthropic purpose in life. Because the ultimate goal is to serve, leaders high in altruistic calling will put others' interests ahead of their own and will diligently work to meet followers' needs.

Emotional healing describes a leader's commitment to and skill in fostering spiritual recovery from hardship or trauma. Leaders using emotional healing are highly empathetic and great listeners, making them adept at facilitating the healing process. Leaders create environments that are safe for employees to voice personal and professional issues. Followers that experience personal traumas will turn to leaders high in emotional healing.

Wisdom can be understood as a combination of awareness of surroundings and anticipation of consequences, similarly described by clas- 
sic philosophers (Kant, 1978; Plato, 1945). When these two characteristics are combined, leaders are adept at picking up cues from the environment and understanding their implications. Leaders high in wisdom are characteristically observant and anticipatory across most functions and settings (Bierly et al., 2000). Wisdom is the ideal of perfect and practical, combining the height of knowledge and utility.

Persuasive mapping describes the extent that leaders use sound reasoning and mental frameworks. Leaders high in persuasive mapping are skilled at mapping issues and conceptualizing greater possibilities and are compelling when articulating these opportunities. They encourage others to visualize the organization's future and are persuasive, offering compelling reasons to get others to do things.

Organizational stewardship describes the extent that leaders prepare an organization to make a positive contribution to society through community development, programs, and outreach. Organizational stewardship involves an ethic or value for taking responsibility for the well-being of the community and making sure that the strategies and decisions undertaken reflect the commitment to give back and leave things better than found. They also work to develop a community spirit in the workplace, one that is preparing to leave a positive legacy.

Several subscales from the original 11 characteristics are absent from the refined construct. These included listening, empathy, community building, and growth. Listening and empathy appear to be skills that aid all aspects of effective leadership and are not unique to servant leadership. We propose that listening and empathy are essential skills for servant leaders because they contribute to the core dimensions of emotional healing and wisdom. The items for community building offered little to the construct empirically. Although servant leaders are adept at building community, this characteristic is not necessarily unique to this style. Growth was also removed from the final construct because it was empirically scattered across the other dimensions. The process of servant leadership explicates a focus on others' needs-professional, developmental, and organizational; this leads to personal and professional growth of others.

\section{The Distinguishing Nature of Servant Leadership}

In this study, servant leadership was a better predictor of LMX quality than was transformational leadership. This finding supports the premise that servant leaders create serving relationships with their followers, which contrasts with transformational leaders, who transcend followers' interests toward organizational goals (Burns, 1978). These findings demonstrate the impact that servant leadership has on the LMX relationship. 
The differences in the relationships between self (leader) and rater (follower) reports of servant leadership and perceptions of organizational effectiveness raise many issues related to perceptions of leadership effectiveness. In this study, leaders reported that their organizational stewardship was the best predictor of their employees' willingness to perform extra work. However, followers identified leaders' wisdom as most related to their willingness to perform extra work. Similarly, leaders assumed that organizational stewardship and wisdom were most closely related to employee satisfaction. However, followers reported that leaders' emotional healing was most related to their satisfaction. Leaders assumed organizational stewardship was related to their effectiveness, and this was consistent with rater reports.

\section{Limitations}

One of the potential limitations of this study was in the sampling procedure used. Because data were collected from elected officials and their staffs, this sample cannot be classified as a probability sample. However, because the participant response rate was well more than $80 \%$ and the participating leaders serve communities of varied populations, we believe we have a good representation of elected leaders. We believe the advantage of sampling elected officials outweighs many of the inherent sampling challenges associated with this population-particularly for studying this construct. Generalization to the private sector may require additional field research.

There is a snowball effect in the sampling procedure because elected officials were asked to distribute materials to their staff to complete the rater versions of the questionnaires. This procedure takes away much of the randomness of the sample. However, elected officers were not asked to select individuals but rather to distribute questionnaires to all of their staff, thus limiting some of the potential bias in rater selection. An alternative strategy may have been to obtain a list of staff members for each elected official and then randomly distribute rater materials to complete and return to the researchers. It may be argued that having elected officials distribute the materials contributed to the high response rates obtained in this sampling procedure and signaled to raters a sincere desire for candid assessment to guide potential leadership development.

Another concern was the assumption of independent observations because multiple raters assessed each leader. Because leaders develop different leadership exchanges with each employee (Graen \& Uhl-Bien, 1995), independent observations are not compromised using this procedure. Because our level of analysis was at the dyadic level, the procedures used were reasonable. 
Objective measures of performance (as opposed to subjective ratings) would enhance the predictive validity of the work. In this study, performance was measured using a subjective response from leaders and raters. An objective measure, one that quantifies productivity or performance, would provide richness to the analysis. Also, multiple source methods may be incorporated to better control for response bias in the data. Because raters assessed leaders' servant leadership and their effectiveness, there is likely single- method bias. This tends to inflate relationships because of the subjectivity of tests and may skew predictive validity. This concern is readily correctable in future studies by planning research designs to incorporate multiple methods.

\section{Future Research Opportunities}

An operational measure of servant leadership leads to many research questions. A major tenet of servant leadership proposes that followers will become healthier, wiser, freer, more autonomous, and more likely to become servants themselves (Greenleaf, 1970). The extent that servant leadership fosters emotional health, organizational wisdom, and self-determination provides key research opportunities to test these assertions.

Servant leadership may precede other positive organizational outcomes, such as organizational citizenship behavior, organizational commitment, worker engagement, and other measures of performance. Other positive organizational behavior theories, such as political skills, authenticity, or prosocial motivations, may affect servant leadership. Organizations needing greater creativity, wisdom, and intelligence require a selfless leader (Sternberg, 2003).

For wisdom, the prime challenge is to use intelligence, creativity, and experience for a common good. Sternberg (2003) argued that this requires individuals to hold a vision beyond self, immediate family, or social identity. The second challenge is to balance interests (own, others, and institutional) during the long and short terms. The third challenge is to genuinely understand other points of view and incorporate them into decisions. Servant leaders, with their altruistic calling, emotional healing, wisdom, persuasive mapping, and organizational stewardship, provide opportunities for these attributes to thrive. The extent that servant leaders foster organizational wisdom is a promising line of empirical inquiry.

The antecedents of servant leadership also provide research opportunities. For example, such variables as emotional intelligence, sources of motivation, flexibility, and openness to experience, or such situational variables as education, bases of social power, early childhood experiences, organizational culture, and exposure to servant leaders, all may 
serve as antecedents. Research is also needed on the hereditary and environmental nature of servant leadership.

\section{Practical Implications}

The excitement surrounding servant leadership may be justified, as it appears strong relationships with positive outcomes such as employees' extra effort, employees' satisfaction, and perceptions of organizational effectiveness were found. Organizations may look for opportunities to recruit individuals who possess servant leadership characteristics. Leadership development opportunities exist to enhance managers' servant leadership skills. The measure developed may be used for pre- and post-testing of servant leadership attributes in leadership development initiatives. Individuals possessing servant leadership characteristics may infuse greater emotional health and wisdom and a legacy of service-oriented individuals.

\section{Appendix}

\section{The Servant Leadership Questionnaire Items}

Altruistic calling $(\alpha=.82)$

01 This person puts my best interests ahead of his/her own.

03 This person does everything he/she can to serve me.

35 This person sacrifices his/her own interests to meet my needs.

46 This person goes above and beyond the call of duty to meet my needs.

Emotional healing $(\alpha=.91)$

05 This person is one I would turn to if I had a personal trauma.

16 This person is good at helping me with my emotional issues.

27 This person is talented at helping me to heal emotionally.

38 This person is one that could help me mend my hard feelings.

Wisdom $(\alpha=.92)$

06 This person seems alert to what's happening.

09 This person is good at anticipating the consequences of decisions.

17 This person has great awareness of what is going on.

28 This person seems in touch with what's happening.

50 This person seems to know what is going to happen.

Persuasive mapping $(\alpha=.87)$

07 This person offers compelling reasons to get me to do things.

08 This person encourages me to dream "big dreams" about the organization.

18 This person is very persuasive. 
29 This person is good at convincing me to do things.

40 This person is gifted when it comes to persuading me.

Organizational stewardship $(\alpha=.89)$

21 This person believes that the organization needs to play a moral role in society.

34 This person believes that our organization needs to function as a community.

43 This person sees the organization for its potential to contribute to society.

45 This person encourages me to have a community spirit in the workplace.

54 This person is preparing the organization to make a positive difference in the future.

\section{References}

Akuchie, N. D. (1993). The servants and the superstars: An examination of servant leadership in light of Matthew 20: 20-28. The Christian Education Journal, 16, 39-43.

Avolio, B. J. (1999). Full leadership development: Building the vital forces in organizations. Thousand Oaks, CA: Sage.

Avolio, B. J., \& Locke, E. E. (2002). Philosophies of leader motivation: Altruism versus egoism. Leadership Quarterly, 13, 169-191.

Awamleh, R., \& Gardner, W. L. (1999). Perceptions of leader charisma and effectiveness: The effects of vision content, delivery, and organizational performance. Leadership Quarterly, 10, 345-374.

Barbuto, J. E., \& Wheeler, D. W. (2002). Becoming a servant leader: Do you have what it takes? NebGuide G02-1481-A. Lincoln: University of Nebraska, Nebraska Cooperative Extension.

Barling, J., Slater, F., \& Kelloway, E. K. (2000). Transformational leadership and emotional intelligence: An exploratory study. Leadership \& Organization Development Journal, 21(3), 157-161.

Bar-Tal, D. (1976). Prosocial behaviors: Theory and research. New York: John Wiley.

Bass, B. M. (1985). Performance beyond expectations. New York: Free Press

Bass, B. M. (2000). The future of leadership in learning organizations. The Journal of Leadership Studies, 7, 18-40.

Bass, B. M., \& Avolio, B. J. (1994). Improving organizational effectiveness through transformational leadership. Thousand Oaks, CA: Sage.

Bass, B. M., \& Steidlmeier, P. (1999). Ethics, character, and authentic transformational leadership. Leadership Quarterly, 10, 181-217.

Bechler, C., \& Johnson, S. D. (1995). Leadership and listening: A study of member perceptions. Small Group Research, 26, 77-85.

Bierly, P. E., Kessler, E. H., \& Christensen, E. W. (2000). Organizational learning, knowledge and wisdom. Journal of Organizational Change Management, 13, 595-618.

Block, P. (1996). Stewardship: Choosing service over self-interest. San Francisco: Berrett-Koehler.

Brief, A. P., \& Motowidlo, S. J. (1986). Prosocial organizational behaviors. Academy of Management Review, 11, 710-725.

Burns, J. M. (1978). Leadership. New York: Harper and Row. 
Bycio, P., Hackett, R. D., \& Allen, J. S. (1995). Further assessments of Bass' (1985) conceptualization of transactional and transformational leadership. Journal of Applied Psychology, 30, 468-478.

Caruso, D. R., Mayer, J. D., \& Salovey, P. (2002). Emotional intelligence and emotional leadership. In R. E. Riggion, S. E. Murphy, \& F. J. Pirozzolo (Eds.), Multiple intelligences and leadership (pp. 63-99). Mahwah, NJ: Lawrence Erlbaum.

Choi, Y., \& Mai-Dalton, R. R. (1998). On the leadership function of self-sacrifice. Leadership Quarterly, 9(4), 1-20.

Coleman, A. (1998, December). Legacy leadership: Stewardship and courage. Health Progress, pp. 28-30, 42.

Conger, J. A., \& Kanungo, R. N. (1987). Toward a behavioral theory of charismatic leadership in organizational settings. Academy of Management Review, 12, 637-647.

Dacher, E. S. (1999). Loving openness and the healing relationship. Advances in MindBody Medicine, 15(1), 32-43.

Davis, J. H., Schoorman, F. D., \& Donaldson, L. (1997). Toward a stewardship theory of management. Academy of Management Review, 22, 20-47.

Devellis, R. (1991). Scale development: Theory and applications. London: Sage.

Druskat, V. U., \& Pescosolido, A. T. (2002). The content of effective teamwork mental models in self-managing teams: Ownership, learning, and heedful interrelating. Human Relations, 55, 283-314.

Eisenberg, N. (1982). Introduction. In N. Eisenberg (Ed.), The development of pro-social behavior (pp. 1-21). New York: Academic Press.

Emmerich, R. (2001). Motivating employees during tough times. Business Credit, 103(7), 10-12.

Fabrigar, L. R., Wegener, D. T., MacCallum, R. C., \& Strahan, E. J. (1999). Evaluating the use of exploratory factor analysis in psychological research. Psychological Methods, 3, 272-299.

Falbe, C. M., \& Yukl, G. (1992). Consequences for managers of using single influence tactics and combinations of tactics. Academy of Management Journal, 35, 638-653.

Farling, M. L., Stone, A. G., \& Winston, B. E. (1999). Servant leadership: Setting the stage for empirical research. Journal of Leadership Studies, 6, 49-72.

Fry, L. W. (2003). Toward a theory of spiritual leadership. Leadership Quarterly, 14, 693-727.

Giltmier, J. W. (1990). On stewardship ethics among land leaders. Journal of Soil \& Water Conservation, 45(6), 27-30.

Godshalk, V. M., \& Sosik, J. J. (2000). Does mentor-protégé agreement on mentor leadership behavior influence the quality of a mentoring relationship? Group \& Organization Management, 25, 291-317.

Goffee, R., \& Jones, G. (2001). Followership. Harvard Business Review, 79(11), 148.

Graen, G. B., \& Uhl-Bien, M. (1995). Relationship-based approach to leadership: Development of leader-member exchange (LMX) theory of leadership over 25 years: Applying a multilevel multi-domain approach. Leadership Quarterly, 6, 219-247.

Graham, J. W. (1991). Servant-leadership in organizations: Inspirational and moral. Leadership Quarterly, 2(2), 105-119.

Greenleaf, R. K. (1970). The servant as a leader. Indianapolis, IN: Greenleaf Center. Greenleaf, R. K. (1972). The institution as servant. Indianapolis, IN: Greenleaf Center. Greenleaf, R. K. (1974). Trustees as servants. Indianapolis, IN: Greenleaf Center. 
Greenleaf, R. K. (1996). On becoming a servant leader. San Francisco: Jossey-Bass.

Grier, J. W., \& Burk, T. (1992). Biology of animal behavior (2nd ed.). St. Louis, MO: Mosby Year Book.

Hawkinson, J. R., \& Johnston, R. K. (1993). Servant leadership: Vol. 2. Contemporary models and the emerging challenge. Chicago: Covenant.

Hinkin, T. R., \& Schriesheim, C. A. (1989). Development and application of new scales to measure the French and Raven (1959) bases of social power. Journal of Applied Psychology, 74, 561-567.

Hurley, A. E., \& Scandura, T. A. (1997). Exploratory and confirmatory factor analyses: Guidelines, issues, and alternatives. Journal of Organizational Behavior, 18, 667-683.

Johnson, S. D., \& Bechler, C. (1998). Examining the relationship between listening effectiveness and leadership emergence: Perceptions, behaviors, and recall. Small Group Research, 29, 452-471.

Jöreskog, K. G., \& Sörbom, D. (2003). LISREL 8.54. Moresville, IN: Scientific Software.

Kant, I. (1978). Anthropology from a pragmatic point of view (V. L. Dowdell, Trans.). Carbondale: Southern Illinois University Press. (Original work published 1798)

Kanungo, R. N., \& Conger, J. A. (1993). Promoting altruism as a cooperative goal. Academy of Management Executive, 7, 37-48.

Kramer, R. (1997). Leading by listening: An empirical test of Carl Rogers's theory of human relationship using interpersonal assessments of leaders by followers. Dissertation Abstracts International Section A: Humanities \& Social Sciences, 58, 514.

Krebs, D. L., \& Miller, D. T. (1985). Altruism and aggression. In G. Lindzey \& E. Aronson (Eds.), The handbook of social psychology (Vol. 2, 3rd ed., pp. 1-71). New York: Random House.

Longman, T. (2002). How to read proverbs. Downers Grove, IL: InterVarsity Press.

Lowe, K. B., Kroeck, K. G., \& Sivasubramaniam, N. (1996). Effectiveness correlates of transformational leadership: A meta-analytic review of the MLQ literature. Leadership Quarterly, 7, 385-425.

Peck, M. S. (1998). Servant-Leadership training and discipline in authentic community. In L. C. Spears (Ed.), Reflections on leadership (pp. 87-98). New York: John Wiley.

Perrewe, P. L. (2000). Political skill: The antidote for workplace stressors. Academy of Management Executive, 14(3), 115-124.

Pescosolido, A. T. (2002). Emergent leaders as managers of group emotions. Leadership Quarterly, 13, 583-599.

Ping, P. F., \& Yukl, G. A. (2000). Perceived effectiveness of influence tactics in the United States and China. Leadership Quarterly, 11, 251-266.

Plato. (1945). The republic of Plato (F. M. Cornford, Trans.). New York: Oxford University Press.

Podsakoff, P. M., \& Organ, D. W. (1986). Self-reports in organizational research: Problems and prospects. Journal of Management, 12, 531-544.

Polleys, M. S. (2002). One university's response to the anti-leadership vaccine: Developing servant leaders. Journal of Leadership Studies, 8(3), 117-130.

Price, T. L. (2003). The ethics of authentic transformational leadership. Leadership Quarterly, 14, 67-81.

Revelle, W., \& Rocklin, T. (1979). Very simple structure: An alternative procedure for estimating the optimal number of interpretable factors. Multivariate Behavioral Research, 14, 403-414. 
Sendjaya, S., \& Sarros, J. C. (2002). Servant leadership: Its origin, development, and application in organizations. Journal of Leadership and Organization Studies, 9, 47-64.

Shuster, J. (1994). Transforming your leadership style. Association Management, 46(1), $39-43$.

Smith, B. N., Montagno, R. V., \& Kuzmenko, T. N. (2004). Transformational and servant leadership: Content and contextual comparisons. Journal of Leadership and Organizational Studies, 10, 80-91.

Snodgrass, K. R. (1993). Your slaves - An account of Jesus' servant leadership in the New Testament. In J. R. Hawkinson \& R. K. Johnstone (Eds.), Servant leadership (Vol. 1, pp. 17-19). Chicago: Covenant.

Sosik, J. J., \& Megerian, L. E. (1999). Understanding leader emotional intelligence and performance: The role of self-other agreement on transformational leadership perceptions. Group \& Organization Management, 24, 367-390.

Spears, L. C. (1995). Reflections on leadership: How Robert K. Greenleaf's theory of servant- leadership influenced today's top management thinkers. New York: John Wiley.

Spears, L. C. (2002). Introduction: Tracing the past, present and future of servantleadership. In L. C. Spears (Ed.), Focus on leadership (pp. 1-18). New York: John Wiley.

Srivastva, S., \& Cooperrider, D. L. (1998). Organizational wisdom and executive courage. San Francisco: New Lexington Press.

Sternberg, R. J. (2003). WICS: A model of leadership in organizations. Academy of Management Learning and Education, 2, 386-401.

Sturnick, J. A. (1998). Healing leadership. In L. C. Spears (Ed.), Insights on leadership (pp. 185-193). New York: John Wiley.

Temkin, L. S. (1993). Inequality. New York: Oxford University Press.

Towler, A. J. (2003). Effects of charismatic influence training on attitudes, behavior, and performance. Personnel Psychology, 56, 363-382.

Weber, M. (1947). The theory of social and economic organizations (T. Parsons, Trans.). New York: Free Press. (Original work published 1922)

Weymes, E. (2003). Relationships not leadership sustain successful organizations. Journal of Change Management, 3, 319-332.

Wolff, S. B., Pescosolido, A. T., \& Druskat, V. U. (2002). Emotional intelligence as the basis of leadership emergence in self-managing teams. Leadership Quarterly, 13, 505-522.

John E. Barbuto, Jr. is an associate professor of leadership in the Department of Agricultural Leadership, Education and Communication at the University of Nebraska- Lincoln. His research interests include work motivation, servant leadership, antecedents of leadership, and leadership education.

Daniel W. Wheeler is professor of leadership and head of the Department of Agricultural Leadership, Education and Communication at the University of Nebraska- Lincoln. His research interests include servant leadership, spirituality, organizational development, and faculty development. 